\title{
Grieving over the Degradation of Nature in Rachel Carson's Silent Spring
}

\author{
Kamelia Talebian Sedehi \\ Payam Noor of Isfahan, Iran
}

\begin{abstract}
Rachel Carson's Silent Spring focuses on the loss of species as a result of toxic contamination and pesticides. The loss of nature and environment affected people and led them to grieve. The term environmental melancholia which is used by Renee Lertzman deals with the grief and mourning over the loss of nature. Therefore, the current paper intends to shed light on Silent Spring by applying Lertzman's environmental melancholia. As people face the degradation of the nature and they are unable to take any action, they will lead to melancholia. Therefore, this paper will indicate the ways people contribute in nature saving or its improvement based on Silent Spring. Besides the article will explain how to take care of the environment and nature.
\end{abstract}

Index Terms —environmental melancholia, Silent Spring, degradation, loss, pesticide, nature

\section{INTRODUCTION}

Melancholia is the loss that subject experiences in his life. Sedehi et al., notes that various philosophers and critics discussed melancholia in different disciplines; therefore, the object of loss should have a huge effect on people's lives that leads them to mourning and grieving (2015). One of these critics is Julia Kristeva who considered loss of mother as the cause of melancholia. As the melancholic subject cannot communicate this loss with others; he isolates himself (Rosli and Sedehi 2014). However the main critic who connects nature and melancholia is Renee Lertzman. As the natural environment is the subject of exploitation, chemical products and degradation, people have the sense of loss within themselves. They cannot have the experience of outdoors as they had before. These concerned people are worried about natural environment and at the same time, they cannot do anything as fear and anxiety of future made them paralyzed. This inaction is response to environmental degradation which leads people to melancholia. As Lertzman noted "the issue of loss and mourning (in the face of ecological degradation) and what it means, quite simply, to live in a world presented as continually under threat" should be studied by scientists (2015). On the other hand, there are some other people who do not care about the ecological degradation. Therefore, the question is how we can motivate people care more about nature and save it.

As the use of chemicals is increased these days, water, soil, fauna and flora are in danger. When people have less contact with nature, they will be led to melancholia and they will experience depression. This paper intends to indicate how environmental melancholia happens and provide the solutions for ecological degradation. In addition to intoxication of the nature and defrostration, "ozone depletion and a warming atmosphere" are considered as part of environmental destruction (Lertzman 2015).

\section{ANALYSIS}

As the The Silent Spring opens, farmers use the pesticides and they destroyed the nature by them. Moreover, the pesticides affected the people.

Then a strange blight crept over the area and everything began to change. Some evil spell had settled on the community: mysterious maladies swept the flocks of chicken; the cattle and sheep sickened and died. Everywhere was a shadow of death. The farmers spoke of much illness among their families. In the town the doctors had become more and more puzzled by new kinds of sickness appearing among their patients. There had been several sudden and unexplained deaths, not only among adults but even among children, who would be stricken suddenly while at play and die within a few hours. (Carson 2000)

It somehow shows that the end of nature will be the end of humans. As "the history of life on earth has been a history of interaction between living things and their surroundings. To a large extent, the physical form and the habits of the earth's vegetation and its animal life have been molded by the environment" (Carson 2000). Humans and environment lived peacefully together in the past. However, after a passage of time humans destroyed the nature by their activities. "The most alarming of all man's assaults upon the environment is the contamination of air, earth, rivers, and sea with dangerous and even lethal materials" (Carson 2000). They not only killed the pests but the natural environment as the exposure of chemical products to sun light can change the formula of the product; therefore, not only the pest, but also the plants are killed. If nature is destroyed, it will take so much time to recover as "it took hundreds of millions of years 
to produce the life that now inhabits the earth" (Carson 2000). In fact, contamination of the natural world is a wrong that must be righted; however, humans are ignorant and they do not have any intention to preserve the environment.

The farmers use pesticides; however, they should be called "biocides" as they kill other organism, flora and fauna (Carson 2000). However, "all this is not to say there is no insect problem and no need of control. I am saying, rather, that control must be geared to realities, not to mythical situations, and that methods employed must be such that they do not destroy us along with the insects" (Carson 2000). The method of killing pests and insects should be changed and the process should be rationalized.

In order to save the nature, humans' contribution is to gain knowledge of "the basic of animal populations and their relations to their surroundings" (Carson 2000). People do not use the knowledge as they do not care about the nature. "We allow the chemical death rain to fall as though there were no alternative, whereas in fact there are many and our ingenuity could soon discover many more if given opportunity" (Carson 2000). People just take everything easy as it is easier not to be bothered than taking actions.

No one pays attention to environment health as "arsenic- contaminated environments have also caused sickness and death among horses, cows, goats, pigs, deer, fishes and bees; despite this record arsenal sprays and dusts are widely used" (Carson 2000). But people do not take any action. It is not animals' life in danger but also humans are not safe either. "Farmers using arsenic dusts over long periods have been afflicted with chronic arsenic poisoning" (Carson 2000). Alderin which is a type of insecticides, "projects a menacing shadow into the future, the shadow of sterility" (14). There will be no animal as the animals will be barren. Because of pesticides, humans' and animals' life will be in danger. First they will show some symptoms of the illnesses and gradually they will die. "The movements of the whole body become uncoordinated: tremors, muscular spasms, convulsions, and death quickly result" (Carson 2000). The pesticides have very dangerous effects on whole environment. The pesticides are not only dangerous for those who are exposed to it but even for the doctors who treat the poisoned patients "unless they wear rubber gloves in handling the victims of poisoning" (Carson 2000).

Besides killing the flora and fauna indirectly by using pesticides, human pollute the water as well. Though "water must also be thought of in terms of the chains of life it supports" (Carson 2000) still people pollute it by throwing rubbish in it. The pesticides can also pollute the soil. Therefore, the crop will be polluted as well, and "a menace that remains as long as the insecticide contamination is in the soil" (Carson 2000). Therefore, there will be a vicious circle of contaminated soil and later crop and human's illness. By using pesticides, humans sacrifice nature, humans and generally the whole environment. "Now millions of acres of sagebrush lands are sprayed each year" (Carson 2000)... "What are the results?"... "The antelope and the grouse will disappear along with the sage. The deer will suffer, too, and the land will be poorer for the destruction of the wild things that belong to it. Even the livestock which are the intended beneficiaries will suffer; no amount of lush green grass in summer can help the sheep starving in the winter storms for lack of the sage and bitterbrush and other wild vegetation of the plains" (Carson 2000). The whole environment will suffer from loss of sage and humans are ignorant as they only think of getting rid of the pests without paying attention to the side effects of those pesticides. Later on, people will mourn as they lose the familiar ecosystem and its inhabitants (Erney 2006).

Some people are even worst. They are so irresponsible toward their work and environment and they are really careless. "In a southern New England town one contactor finished his work with some chemical remaining in his tank. He discharged this along woodland roadsides where no spraying had been authorized. As a result, the community lost the blue and golden beauty of its autumn roads" (Carson 2000). Because of the irresponsibility of one person, the people should feel the loss of autumn and mourn for the loss of its beauty. "And where are the men who supposedly understand the value of proper habitat for the preservation of wildlife? Too many of them are to be found defending herbicides as 'harmless' to wildlife because they are thought to be less toxic than insecticides" (Carson 2000). No one stands for the right of the environment as they never consider insecticides as a threat to humans or environment. The humans do not want to hear about the negative effects of pesticides as these chemicals are the only ways to get rid of those pests and insects.

However, there are some devoted researchers who spend their life contributing to save nature. They did some research and found out that "once properly treated, an area becomes stabilized, requiring no respraying for at least 20 years" (Carson 2000), furthermore, "here and there the method of vegetation management by selective spraying has been adopted" (Carson 2000). Therefore, there are some new options to preserve the nature. Many researches have been done and indicated that "people spraying their lawns with 2, 4-D and becoming wet with spray have occasionally developed severe neuritis and even paralysis" (Carson 2000)... "Some very recent work indicates that reproduction of birds may be adversely affected by these and certain other herbicides at levels far below those that cause death" (Carson 2000). The researchers have conducted these researches to inform people about the harmful effects of pesticides on nature and humans as well. The results will be fatal so these people will risk their own life.

As we have seen, soil and the living things in and upon it exist in relation of interdependence and mutual benefit. Presumably the weed is taking something from the soil; perhaps it is also contributing something to it. A practical example was provided recently by the parks in a city in Holland. The roses were doing badly. Soil samples showed heavy infestations by tiny nematode worms. Scientists of the Dutch Plant Protection Service did not recommend chemical sprays or soil treatments; instead, they suggested that marigolds be planted among the roses. This plant, which 
the purist would doubtless consider a weed in any rosebed, releases an excretion from is roots that kills the soil nematodes. The advice was taken; some beds were planted with marigolds, some left without as controls. The results were striking. With the aid of the marigolds the roses flourished; in the control beds they were sickly and dropping. Marigolds are now used in many places for combating nematodes. (Carson 2000)

Therefore, sometimes people should leave the nature to handle things itself. As people intend to control the weeds, they change the whole cycle of nature of by meddling in it. They are damaging the nature unconsciously. For example, "in the same way, and perhaps quite unknown to us, other plants, that we ruthlessly eradicate may be performing a function that is necessary to the health of the soil" (Carson 2000). People are just eradicating the plants without noticing its consequences. "The history of the recent century has its black passages- the slaughter of buffalo on the western plains, the massacre of the shorebirds by the market gunners, the near- extermination of the egrets for their plumage. Now, to these and others like them, we are adding a new chapter and a new kind of havoc- the direct killing of birds, mammals, fishes and indeed practically every form of wildlife by chemical insecticides indiscriminately sprayed on the land" (Carson 2000). Men killed animals for the sake of financial benefits; however, in this case, they kill animals and destroy environment only because they want to get rid of insects. "Under the philosophy that now seems to guide our destinies, nothing must get in the way of the man with the spray gun. The incidental victims of his crusade against insects count as nothing; if robins, pheasants, raccoons, cats, or even livestock happen to inhabit the same bit of earth as the target insects and to be hit by the rain of insect-killing poisons no one must protest" (Carson 2000). They do not care about the environment or the ecosystem, they only care about their project which is spraying the insects. "On the one hand conservationists and many wildlife biologists assert that the losses have been severe and in some cases even catastrophic. On the other hand the control agencies tend to deny flatly and categorically that such losses have occurred, or that they are of any importance if they have. Which view are we to accept?" (Carson 2000). People want to emphasize the losses but the agencies deny that as their profit is in insecticides and pesticides. They do not care about the nature, its degradation and different losses. As the men in power do not bother themselves to conserve the nature,

The concept of public apathy is often invoked in response to a perceived absence of care towards environmental quality of protection demonstrated by either the absence of certain practice, or an apparent disregard for conservation. (Lertzman 2015)

Unlike some careless people, there are some people who really care about whatever happens in the ecosystem. "Within a few days after the dusting operation, the Detroit Audubon Society began receiving calls about the birds. According to the Society's secretary, Mrs. Ann Boyes, 'The first indication that the people were concerned about the spray as a call I received on Sunday morning from a woman who reported that coming home from church she saw an alarming number of dead and dying birds. The spraying there had been done on Thursday" (Carson 2000)... "Birds picked up in a dying condition showed the typical symptoms of insecticide poisoning- tremoring, loss of ability to fly, paralysis, convulsions" (Carson 2000). These people cannot do anything to stop the local industry or use of pesticide as they are not in power. As a result of feeling incapable to do anything, they are led to melancholia and mourn the loss of beautiful ecology. The reports show the fatal effect of insecticides not only on birds, but all the species of animals, even humans are affected by insecticides and they showed some symptoms of "nausea, vomiting, chills, fever, extreme fatigue, and coughing" (Carson 2000). People can never accept that they lost nature because of their stupidity, lack of knowledge and attention. "Heavy losses were occurring among wildlife and domestic animals" (Carson 2000), but no one is concerned about that. These caring people contacted the nature saving companies to do something about the degradation of nature as the loss of nature concern them a lot.

Humans intend to kill the insects but these poisonous chemicals kill all kinds of species. Humans will mourn for the loss of these creatures as they are "innocent of any harm to man. Indeed, by their very existence, they and their fellows make his life more pleasant. Yet he rewards them with a death that is not only sudden but horrible" (Carson 2000). The animals are pleasant to look at or to listen to, but humans kill them by using these insecticides. As a result of those poisonous chemicals, many birds did not return back to United States. "This sudden silencing of the song of the birds, this obliteration of the color and beauty and interest they lend to our world have come about swiftly insidiously, and unnoticed by those whose communities are as yet unaffected" (Carson 2000). People mourn the loss of some birds and their beauty. Some of the people really care about the nature and its changes as "from the town of Hinsdale, Illinois, a housewife wrote in despair to one of the world's leading ornithologists, Robert Cushman Murphy, Curator Emeritus of Birds at the American Museum of Natural History" (Carson 2000). She grieved the loss of beautiful nature and birds and asks for help. For her, the nature is "a form of sanctuary that has been lost" (Lertzman 2015). She accuses all the insecticides that made lively nature into a depressing environment. Based on her opinion, "it is hard to explain to the children that the birds have been killed off, when they have learned in school that a Federal law protects the birds from killing or capture, 'will they ever come back?" (Carson 2000). The animals' life was threatened so how these birds can return again to the same environment. The nature is devoid of those species because of inconsiderate people. "There was not a sound of the song of a bird. It was eerie, terrifying" (Carson 2000). The people are used to these birds and now they mourn the loss. "One story might serve as the tragic symbol of the fate of the birds- a fate that has already overtaken some species, and that threatens all" (Carson 2000). These people should recognize the reasons behind the ruin of "the inherent beauty of a bucolic and autumnous nonhuman world" (Bukeavich 2003). The life of all the species is at risk as humans use all those of pesticides without thinking. "These treetop feeders are affected either directly by 
easting poisoned insects or indirectly by a shortage of food" (Carson 2000). When people meddle in natural phenomenon, they destroy the whole cycle of life.

Other people also reported the case of animal loss within certain areas. "I am dreading the days to come soon now when many beautiful birds will be dying in our back yard" (Carson 2000). She grieves the loss of birds as she is concerned about her local ecology. Not only the plants and animals but also sea creatures are in danger. She is acknowledging the loss of nature as she has "sense of powerlessness, and efficiency" (Lertzman 2015). She asked the responsible people to help the nature, but no one care about the ecology. "Soon after the spraying had ended there was unmistakable signs that all was not well. Within two days dead and dying fish, including many young salmon, were found along the banks of the stream" (Carson 2000). DDT is harmful to fishes and all the sea creatures. As the sea creatures are in danger by DDT, "the future of salmon fisheries in New Brunswick may well depend on finding a substitute for drenching forests in DDT" (Carson 2000). But the question is whether they really care about the loss of sea creatures or not. The living organisms of the ocean face exponential danger and most of the humans are not bothered. The poisoned water becomes the tomb for water species. The paradoxical part is that humans are not even concerned about their lives.

Like the constant dripping of water that in turn wears away the hardest stone, this birth-to-death contact with dangerous chemicals may in the end prove disastrous. Each of these recurrent exposures, no matter how slight, contributes to the progressive buildup of chemicals in our bodies and so to cumulative poisoning. (Carson 2000)

The insecticides and pesticides remain in human bodies and create cancerous cells; however, the people whose benefit is in the industry of chemical poisons intend to deny it as their profit is in those products. Whatever the humans did in nature destroyed the balance and cycle of nature. "The balance of nature is not the same today as in Pleistocene times, but it is still there: a complex, precise, and highly integrated system of relationships between living things which cannot safely be ignored any more than the law of gravity can be defined with impunity by a man perched on the edge of a cliff' (Carson 2000).Instead of improving the situation, the meddling in nature destroyed lives of the species and in turn led the concerned people to melancholia as they mourn these losses. To save the nature, Patrick mentioned that there were two different methods of writing about the nature and informing people about its degradation and second one providing scientific proof for people about the negative effects of industry and pesticides (2007). However, based on Tesh, some of these environmental movements and nature preserving are failed as the goals which may lead to public health are not well researched therefore there will be no change in the status quo (1994).

\section{CONCLUSION}

From the first day of creation man and nature have been connected. As humans progressed and used technology, they exploited the nature and ruined it. The degradation of nature led to their melancholia and they mourn in their lives. However, not all the people are concerned about the degradation of the nature. As a result, it is the scientists' duties to inform people about the negative effects of technology, specifically use of biocides in nature. The writers and journalist can write more about the connection of man and nature to bring awareness to man. This way, people might reconsider the use of chemicals in daily basis.

\section{REFERENCES}

[1] Bukeavich, N. (2003). Fictions of Nature: Ecology, Science, and Culture in Twentieth Century British Literature. Order No. 3051873 Morgatown, West Virginia. Ann ArborProQuest. 23 Feb. 2016.

[2] Carson, R. (2000). Silent Spring. New York: Penguin Classics.

[3] Erney, H. G. (2006). Modernity and globalization in contemporary literature: A postcolonial-ecocritical approach. Order No. 1411545 Emory University. Ann ArborProQuest. 23 Feb. 2016.

[4] Lertzman, R. (2015). Environmental Melancholia: Psychoanalytic dimensions of engagement. New York: Routledge.

[5] Patrick, A. M. (2007). Explorations in Ecocritical Theory and Practice. Georgia: Georgia University Press. 141-153.

[6] Rosli, T and Kamelia Talebian Sedehi. (2014). Melancholic Celie in The Color Purple. Pertanika Journal of Social Sciences and Humanities 22 (2): 621- 631.

[7] Sedehi, K. T, Rosli Talif, Wan Roselezam Wan Yahya and Hardev Kaur. (2015). Melancholic Mem in Third Life of Grange Copeland. Pertanika Journal of Social Sciences and Humanities 23 (4): 967- 978.

[8] Tesh, S, N. (1994). Causal Debates in Environmentalism. Journal of Public Health Policy (15), 298-309.

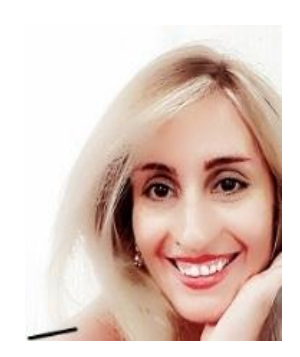

Kamelia Talebian Sedehi is $\mathrm{PhD}$ of English Literature. She received her doctorate from Universiti Putra Malaysia in 2016. She received her B.A. (2009) and M.A. (2011) in English Literature from University of Isfahan. Her research interests are melancholia, trauma, sexuality, gender studies and interdisciplinary topics. She has presented at various national and international conferences and is an experienced university lecturer and teacher. Currently, she is working at Payam Noor University (Isfahan branch), Iran. 